\title{
Cultura e desenvolvimento: perspectivas históricas e contemporâneas para o Estado do Amapá
}

\author{
Heluana Quintas de Lima ${ }^{1}$, Pablo Sebastian Moreira Fernandez ${ }^{2}$ e \\ José Francisco de Carvalho Ferreira ${ }^{3}$
}

\begin{abstract}
1 Universidade Federal do Amapá, Brasil. E-mail: heluanaquintas@gmail.com
2 Universidade Federal do Rio Grande do Norte, Brasil. E-mail: pablosmfernandez@gmail.com

3 Universidade Federal do Amapá, Brasil. E-mail: zfcofer@gmail.com
\end{abstract}

\begin{abstract}
RESUM 0: 0 presente artigo tem como objetivo demonstrar a relação histórica e epistemológica existente entre cultura e desenvolvimento, compreendendo que a partir deste breve percurso seja possível elucidar sobre o papel da cultura conforme a compreensão de desenvolvimento colocada na contemporaneidade. Constatou-se que o crescente interesse pela dimensão cultural do desenvolvimento, ampliou esta noção e tornou-os indissociáveis, provocando variadas leituras sobre a imprescindibilidade da cultura na globalização e no Direito ao Desenvolvimento, reconhecendo a cultura como essencial à vida humana e à garantia da dignidade desta. Entretanto, este reconhecimento nas Políticas Públicas de Cultura do Amapá se demonstra recente e ainda tímido em sua institucionalização, na interação entre as esferas estatais e na constância da cultura nos planos plurianuais do referido estado.
\end{abstract}

Palavras-chaves: Cultura; Desenvolvimento; Globalização; Direitos Humanos; Amapá.

\section{Culture and development: historical and contemporary perspectives for the Amapá state - Brazil}

\begin{abstract}
This article aims to demonstrate the historical and epistemological relationship between culture and development, understanding that from this brief path it is possible to elucidate the role of culture according to the understanding of development placed in the contemporary world. It was found that the growing interest in the cultural dimension of development widened this notion and made them inseparable, provoking different readings on the indispensability of culture in globalization and on the Right to Development, recognizing culture as essential to human life and guaranteeing the Dignity. However, this recognition in Amapá's Public Policies of Culture is recent and still timid in its institutionalization, in the interaction between state spheres and in the constancy of culture in the multiannual plans of the state.

Keywords: Culture; Development; Globalization; Human rights; Amapá.
\end{abstract}

\section{INTRODUÇÃO}

O Desenvolvimento tem concepções diferentes, manifestando-se mundial, regional e localmente de maneiras variadas. Permite uma multiplicidade de abordagens, ora excludentes, ora complementares e, por isso, está permanentemente sujeito a críticas teórico-metodológicas. As narrativas sobre o 'desenvolvimento' não perfilam exclusivamente teorias científicas (Teoria da Modernização, Teoria do Desenvolvimento Econômico, Teoria do Desenvolvimento Sustentável, etc.), mas também com- 
põem formas de intervir na sociedade. Nesta perspectiva, o desenvolvimento pode ser compreendido como um fenômeno social, visto que atinge uma coletividade de atores beneficiários ou negligenciados, partícipes ou expectadores das estratégias implementadas.

As propostas contemporâneas buscam um enfoque mais integral, holístico ou multidisciplinar, visto que, historicamente, atribuiu-se 'crescimento econômico', 'crescimento do Produto Interno Bruto (PIB)' ou 'incremento na economia' como métrica oficial ou condição exclusiva do desenvolvimento. As recentes abordagens permitiram a ampliação desta noção pautada pela economia, justapondo questões de maior alcance, como a preservação de Recursos Naturais, a dignidade da vida humana e 0 acesso a bens e serviços públicos de qualidade, do mesmo modo que apontam para outras dimensões tais quais a ambiental, a social, a política e a cultural. Esta última, foco deste artigo.

Para tanto, objetiva-se refletir sobre a relação entre cultura e desenvolvimento, seus aspectos históricos e epistemológicos, considerando que estes conceitos interagem e se influenciam mutuamente no decorrer de disputas políticas e de acirramentos ideológicos. Em seguida, busca-se compreender sobre o lugar da cultura no Direito ao Desenvolvimento, considerando os Direitos Humanos como uma plataforma possível para o entendimento da expansão do conceito de desenvolvimento contemporaneamente. Por fim, são analisadas as perspectivas de Política Cultural, enquanto Política Pública para o Desenvolvimento do Amapá. A partir do que se observa: a) a articulação do Amapá ao Sistema Nacional de Cultura (SNC); b) os Planos Plurianuais do Amapá (2004-2015), por entender que nestes se explanam o intento dos governos, através de diretrizes, objetivos e metas, sujeitos a um prazo definido de quatro anos e expressam o espaço ocupado pela Cultura no planejamento do/para o estado; e c) a produção científica, as pesquisas e estatísticas focalizadas na unidade federativa em questão (QUINTAS, 2016).

\section{PERSPECTIVAS HISTÓRICAS E EPISTEM OLÓGICAS DA RELAÇÃO ENTRE CULTURA E DESENVOLVIMENTO}

Um ponto de partida para compreender a relação entre Cultura e Desenvolvimento pode se concentrar nas ideias de Desenvolvimento ao longo do tempo. A partir disso, é possível compreender o lugar da cultura neste processo, desde disputas históricas de poder entre povos distintos às prevalências ideológicas constantes na relação, de tal forma que, embora estes campos se diferenciem por seus princípios e funcionamentos próprios, é possível observar suas mútuas influências.

Desde a antiguidade até o final da Primeira Guerra M undial, imperaram noções de desenvolvimento genéricas que juntavam uma série de ideias sobre história, bemestar da humanidade e transformações decorrentes da economia. Soares-Junior e Quintela (2008), os postulados de Buffon (1707-1788) em sua obra História Natural. 
Nela o europeu seria a meta civilizatória dos povos. Isto conferia respaldo à realidade que se desenhava como natural durante o colonialismo. Aprofundando a questão, Marquês de Condorcet (1743-1794) argumentava que a Europa respeitaria a independência de suas colônias como um processo natural de contribuição à civilização das mesmas. A colonização, portanto, era uma campanha generosa de oportunidades para os povos atrasados. Apresenta-se uma correspondência entre civilização e ocidentalização cuja vigência se estende até a primeira metade do século XX.

Segundo aqueles autores, (op. cit., p. 3):

Condorcet defendia a ideia que a Europa acabaria respeitando a independência de suas antigas colônias e contribuindo com elas a partir da civilização de seus povos (RIST, 2001, p.68). Nessa perspectiva, portanto, a colonização era vista como uma empreitada generosa, visando oferecer oportunidade às sociedades mais atrasadas para 'avançarem' no caminho da civilização.

Os pensadores modernos, a exemplo Vico, Kant, Proudhon, Mill, Hegel e Marx entendem a "história como uma marcha firme da civilização" (op. cit., p. 63) - ainda que a apresentem de forma não linear. Esta visão tem proximidade com o pensamento agostiniano, que concebe a história em sua totalidade, como um processo evolutivo, uma trajetória pelo progresso. Entretanto, Soares-Junior e Quintela (op. cit.) entendem que a multiplicidade cultural característica das sociedades no século XXI não comporta este processo desenvolvimentista visto como natural e linear numa marcha comum pelo progresso.

O 'progresso' constituiu, nos anos de 1930 e 1940, apenas um entre os elementos da noção de Desenvolvimento. Nos anos que se seguiram à Segunda Guerra Mundial, fortaleceu-se esta noção e esclareceu-se que dois terços no mundo é constituída de pobres, descerrando aqueles que estavam dentro e os que estavam fora do desenvolvimento, bem como as vinculações que mantinham tais posições (BURITY, 2007, p. 52-53).

No contexto do fim da Segunda Guerra Muncial, com a derrota do nazismo e a divisão da Alemanha em ocidental (capitalista) e oriental (socialista), emerge a representação dos "três mundos". Em todas essas fases e representações (países desenvolvidos, não-desenvolvidos, subdesenvolvidos), permanece uma mesma correspondência de futuro, de ponto de chegada. Nada havia de ser inventado a partir do lugar, se existiam "os modelos" de Desenvolvimento a serem implementados. A adoção de medidas e o estabelecimento de metas para modernização e liberalização constituiriam, portanto, as condições de saída do subdesenvolvimento (op. cit., p. 54).

De acordo com o autor supracitado, até a década de 1970, a Cultura era empecilho ao Desenvolvimento, que precisava se defrontar com o atraso das populações, com oligarquias locais, especificidades nacionais/locais. 0 Desenvolvimento lidava com um elemento do passado, uma resistência ou tradição a ser superada. Já na passa- 
gem da década de 1970 a 1980, frustradas as expectativas sobre efeitos automáticos do incremento econômico, emerge uma série de questionamentos sobre: a capacidade solitária deste crescimento, o papel do Estado através de políticas públicas como indutor do Desenvolvimento e os impactos negativos dessa indução em algumas sociedades. A partir disso, a Cultura passa a ser requisitada como um componente que poderia evitar a destruição dessas sociedades.

A emergência da Cultura nestes questionamentos encontra eco no discurso ambientalista, no discurso da diferença e da identidade, que se fortalecem a partir de então. Os modelos de Desenvolvimento descontextualizados cedem lugar a narrativas alternativas. Já nos anos de 1980, os dois terços pobres do globo passam a ser representados como subdesenvolvidos ou em desenvolvimento. A hegemonia do discurso neoliberal reposiciona a economia como critério para convergência da política, da cultura e da sociabilidade em busca do Desenvolvimento. "Há um lugar para cultura nessa nova estratégia de Desenvolvimento visceralmente economicista" (op. cit., p. 37), caracterizada pela linguagem do empreendedorismo.

Nos anos de 1990, há uma tentativa de redefinir a ideia neoliberal de Desenvolvimento como resposta às propostas de reforma do Estado que fracassaram nos países em atraso. Como decorrência disso, robustecem-se as críticas dos movimentos (ambientalista, dos que tratavam das narrativas da diferença e da identidade) e vários organismos internacionais passam a promover pesquisas relacionadas à cultura, conforme Burity (op. cit., p. 58). 0 autor destaca estudos do Banco Mundial junto aos Tigres Asiáticos, cuja observância recaía atentamente sobre as virtudes de conversão daquela região ao mercado. A pesquisa apontava que a herança confuciana - pautada pela disciplina e lealdade - consistia de um forte componente cultural condicionante para o desempenho destes países ante a economia mundial.

De tal forma, é importante ponderar sobre o intento de organismos multilaterais principiarem suas agendas no sentido de fazer convergir a lógica cultural de forma a subordina-la à lógica do mercado, como aponta Burity (2007, p. 61). Nota-se que houve não só uma culminância histórica de fracassos e tentativas de readequação do elemento cultural à empreitada econômica como sustentáculo do Desenvolvimento, como também a Cultura se tornou fator da economia pela crescente influência das indústrias culturais, do turismo cultural como gerador de emprego e renda; promovente de inclusão social, através, por exemplo, de grupos principalmente urbanos que escapam da condição de exclusão se integrando à economia e construindo um mercado a partir do local. Burity ((op. cit., p. 59-62) conclui que as estratégias de Desenvolvimento a serem implementadas em contextos locais adquirirão melhores resultados quanto mais valorizarem: a) imprescindibilidade do diálogo com a cultura local; b) a cultura para eficácia das políticas públicas; e c) a participação das pessoas envolvidas como beneficiárias ou atingidas.

A importância dos indivíduos no processo de Desenvolvimento ascende na medida em que as discussões sobre identidade se colocam na modernidade como algo sujeito 
a mudanças e inovações. Mais tarde, observados os deslocamentos de identidades decorrentes da globalização, consolidam-se os questionamentos acerca das intercorrências nos modos de vida estabelecidos, sobre os "sujeitos e sua inserção no mundo [...], do seu lugar na vida social e de si mesmos" (ESCOSTEGUY, 2001, p. 139).

A globalização, aliás, é tema das abordagens históricas propostas por teóricos como Stuart Hall, Néstor Garcia Canclini e Jesús Martín-Barbero, os quais, de acordo com Escoteguy (op. cit., p. 141), apresentam esse "pano de fundo" como uma condição para compreender a preocupação contemporânea com a Cultura. Neste viés histórico, Hall (1997) descreve a centralidade da Cultura a partir da expansão de todas atividades a ela relacionadas - principalmente na segunda metade do século XX - e 0 seu papel constitutivo em todos aspectos da vida social, na consciência popular, desenvolvimento global e no arranjo de seus recursos econômicos e materiais. Esse processo, 0 autor chama de "revoluções culturais", caracterizadas (op. cit., p. 5):

a) Pelas mudanças culturais numa dimensão global que provocam mudanças sociais e deslocamentos culturais: a partir da ampliação dos meios de produção, circulação e trocas culturais mediadas por Tecnologias da Informação e Comunicação; das indústrias culturais como produção de discursos e ramo de negócio partícipe do PIB; da mídia, que ao mesmo tempo que mantém um mercado global, o faz em plena dependência da circulação mundial de informação, conhecimento, capital, investimento, produção de bens, comércio de matéria-prima e marketing de produtos e ideias;

b) Pelas transformações da vida local e cotidiana (vida social): com a instabilidade no emprego, incremento no setor de serviços, envelhecimento da população, queda no número de casamentos, aumento de divórcios, etc. Estas transformações culturais encharcam os sentidos com múltiplos estímulos. Mensagens de celular, de aplicativos que conduzem uma rotina, mostram que estas transformações exigem a expansão da capacidade humana e residem no ambiente doméstico "atrelado pelo consumo, às tendências e modas mundiais. Elas também servem à sofisticação dos instrumentos de controle, vigilância e regulação das sociedades;

c) Pelo impacto na vida interior, na constituição da subjetividade, da identidade e da pessoa como um ator social: 0 autor indica que a identidade emerge do diálogo entre as identificações que adotamos a partir do que é apresentado nos discursos de uma Cultura. Destaca-se a relação do indivíduo com a Cultura no que se revela um imbricamento entre "interior" e "exterior", entre o psíquico e o social.

Assim, a proeminência cada vez maior da Cultura é resultado de um processo de reconhecimento histórico e vivências, que envolve ampliações cognitivas estimuladas pelo uso de novas tecnologias e associadas às indústrias culturais, as quais incidiram nos modos de produção, distribuição, consumo e na própria cultura; engendra também as mudanças na vida social diária e na formação do indivíduo. Em outras palavras, "na contemporaneidade, a cultura comparece como um campo social singular e, de modo simultâneo, perpassa transversalmente todas as esferas societárias, como figura quase 
onipresente" (RUBIM, 2007, p. 148).

Todavia, esse reconhecimento não se deu apartado de transformações epistemológicas. Conforme já salientado, os discursos sobre o Desenvolvimento não compõem inofensivas teorias, como também são formas de provocar intervenções na realidade. Hall $(1997$, p.9) entende que a projeção da cultura em processos globais foi acompanhada também por uma "revolução do pensamento humano" sobre a noção de Cultura, que no lugar de compor uma variável dependente, agora é abordada como "condição constitutiva da vida social". Esta mudança de paradigma denomina-se "Virada Cultural" e está assentada nas mudanças de atitude em relação à linguagem como prática de representação.

Neste panorama, a Cultura é "a soma de diferentes sistemas de qualificação e diferentes formações discursivas" (op. cit., p. 10). De tal forma, e por dependerem do significado, da maneira de viver, das identidades - os processos econômicos, políticos e sociais devem ser compreendidos como práticas culturais. Conforme 0 autor:

isto não significa que os processos econômicos tenham sido reduzidos aos discursos e à linguagem. Significa que a dimensão discursiva ou de significado é uma das condições constitutivas do funcionamento da economia. 0 "econômico", por assim dizer, não poderia funcionar nem teria efeitos reais sem a "cultura" ou fora dos significados e dos discursos. A cultura é, portanto, nestes exemplos, uma parte constitutiva do "político" e do "econômico", da mesma forma que o "político" e o "econômico" são, por sua vez, parte constitutiva da cultura e a ela impõem limites. Eles se constituem mutuamente - o que é outra maneira de dizer que se articulam um ao outro. Assim, para sermos bastante precisos, deveríamos, de fato, reformular a concepção corrente de "cultura" apresentada acima: toda prática social tem condições culturais ou discursivas de existência (op. cit., p. 27).

Em síntese, a "Virada Cultural" de que fala Hall (op. cit.), trata-se da convergência da concepção de Cultura como modo de vida global sedimentado por amplos sistemas de significação abrangendo toda e qualquer forma de atividade social (SOUZA, 2012).

Em face a essas mudanças, o estudo sobre o Desenvolvimento parece requerer um novo paradigma, com a construção de novas categorias analíticas integradas a múltiplos campos de saberes e que reconheçam a complexidade do tema. A noção de Desenvolvimento reflete claramente as consequências das "Revoluções Culturais" e da "Virada Cultural", considerando que: "as próprias mudanças no conceito de Desenvolvimento de forma a incluir outros elementos que não somente o econômico é uma mutação cultural" (op. cit., p. 47). Isso pode ser percebido também como uma reação às acepções economicistas.

De acordo com Sen e Kliksberg (2010, p. 318), o paradigma de Desenvolvimento da Organização das Nações Unidas (ONU) propõe, no escopo comum de suas publicações, a necessidade de parâmetros mais amplos. Assim, para que se evitem reducionismos, convém salientar que a cultura, tal qual a economia, não realiza isoladamen- 
te o Desenvolvimento de um país ou uma região. Portanto, "trata-se de buscar uma visão mais integrada de Desenvolvimento" (op. cit., p. 318). Em outras palavras:

\begin{abstract}
A visão integrada do desenvolvimento considera não apenas os efeitos econômicos, mas igualmente os efeitos sociais e culturais. Nos termos de Donders e Laaksonen (2011, p. 90), trata-se do estabelecimento da relação entre um "entendimento mais descentralizado e amplo de desenvolvimento" e "um conceito de cultura como um aspecto transversal, mutável e fundamental da vida humana", de maneira a consolidar o bem estar como um dos aspectos da dignidade humana, além do próprio entendimento dos direitos culturais como "fator de desenvolvimento humano essencial para a superação da pobreza" (VARELLA, 2014, p. 54-55).
\end{abstract}

$\mathrm{Na}$ esteira da transversalidade, Brant (2009) afirma que é preciso compreender a economia enquanto fenômeno cultural, referindo-se às dinâmicas de trocas e de sociabilidade, às tecnologias de convivência, ao diálogo, às conversações em redes, aos sistemas de intercâmbio de relações reforçados por novas tecnologias. 0 contexto mercadológico no qual a sociedade contemporânea está imersa torna as pessoas "agentes de manutenção e reprodução" (op. cit., p. 112) de um sistema de valores linear e desumano.

Para escapar dessa condição, o autor sugere baseado na United Nations Educational, Scientific and Cultural Organization - Unesco, que é essencial cuidar da dimensão econômica da cultura observando processos de produção, distribuição, troca, uso e consumo de bens simbólicos, complementado por um conjunto de instrumentos de apropriação desses bens, sendo, portanto, necessária "certa insubordinação da cultura em relação [na] construção do bem-estar social em tempos de soberania absoluta dos mercados e do aspecto macroeconômico", de modo que coloquemos "humano em primeiro lugar e a economia a serviço de coexistência de todas as formas de vida de nosso planeta" (op. cit., p. 112).

Para tanto, é salutar que a cultura não seja um fenômeno derivativo da economia. Estas perspectivas guardam estreita relação com a indivisibilidade e universalidade dos Direitos Humanos, os quais também são um produto histórico, resultado de tensões e disputas com consequências globais. Os Direitos Humanos constituem uma reflexão incisiva sobre o papel da Cultura no Desenvolvimento.

\title{
3 CULTURA E DIREITO AO DESENVOLVIMENTO
}

Baseado em Noberto Bobbio, Mata-Machado (2007, p. 2) afirma serem os Direitos Humanos, direitos históricos - e não naturais, como se costuma pensar. Isto porque: "a luta do direito sempre contesta uma ordem anterior", "estão em constante construção" e "sua evolução não se deu de forma pacífica". A própria trajetória até a Declaração dos Direitos Humanos (1948) é exemplo do que aponta Bobbio.

Após as atrocidades cometidas na Segunda Guerra M undial, 48 países-membros da

PRACS: Revista Eletrônica de Humanidades do Curso de Ciências Sociais da UNIFAP 
ONU anunciam a sua declaração de proteção ao indivíduo diante do Estado: a Declaração Universal dos Direitos Humanos - DUDH (1948); além de outros instrumentos jurídicos internacionais que foram aprofundando e refinando normativas sobre a relação Estado, indivíduo, sociedade, comunidades e cooperação, sob os aspectos de defesa e garantia de direitos. Esses tratados internacionais elucubram, assim, um "consenso internacional acerca de parâmetros protetivos mínimos referentes à dignidade humana, isto é, o mínimo ético irredutível que deve ser respeitado pelos Estados" (PIOVESAN, 2002, p. 3).

A universalidade e a indivisibilidade são características da concepção contemporânea de Direitos. "Universais" porque é a condição de pessoa que determina a titularidade dos direitos, e "indivisíveis" porque são garantidos todos os direitos (civis, políticos, sociais, econômicos, sociais, difusos), restando prejuízo a todos os demais quando um deles sofre violação. De tal forma, que a existência real dos direitos humanos depende do reconhecimento integral de todos eles (op. cit.).

Seguindo a linha de Bobbio (apud Mata Machado, 2007, p. 2), os Direitos Humanos como direitos históricos nasceram em circunstâncias diferentes, são resultados de lutas distintas e estão em constante construção (Quadro 1).

Quadro 1 - Caracterização dos Direitos Humanos

\begin{tabular}{|c|c|c|c|}
\hline DIREITOS & CONTEXTO DE SURGIMENTO & $\begin{array}{l}\text { OBJETIVO EM RELA- } \\
\text { ÇÃO AO ESTADO }\end{array}$ & DESCRIÇÃOO \\
\hline Civis & $\begin{array}{l}\text { Estado Liberal, foco no indivíduo, } \\
\text { não ingerência do Estado sobre } \\
\text { as pessoas. Estes direitos surgem } \\
\text { nas disputas contra os Estados } \\
\text { absolutistas e coloniais. }\end{array}$ & $\begin{array}{l}\text { Assegurar a liberda- } \\
\text { de em relação ao } \\
\text { Estado }\end{array}$ & $\begin{array}{l}\text { Direito à vida, à liberdade, à segurança } \\
\text { pessoal, à livre iniciativa, ao comércio, à } \\
\text { propriedade, à livre expressão do pensa- } \\
\text { mento, à resistir, rebelar-se contra qual- } \\
\text { quer tipo de opressão, etc. }\end{array}$ \\
\hline Políticos & $\begin{array}{l}\text { O século XIX, a industrializa- } \\
\text { ção/liberalismo, lógica que levou } \\
\text { ao agravamento de problemas } \\
\text { sociais. }\end{array}$ & $\begin{array}{l}\text { Assegurar o gozo da } \\
\text { liberdade no Estado }\end{array}$ & $\begin{array}{l}\text { Direito de votar e ser votado, associar-se } \\
\text { em partidos políticos a fim de disputar o } \\
\text { poder. Exige o regime democrático, por- } \\
\text { tanto, etc. }\end{array}$ \\
\hline Sociais & $\begin{array}{l}\text { Os Direitos Sociais Econômicos e } \\
\text { Culturais surgiram das lutas } \\
\text { campesinas e do operariado. }\end{array}$ & $\begin{array}{l}\text { Assegurar as liber- } \\
\text { dades por meio do } \\
\text { Estado }\end{array}$ & $\begin{array}{l}\text { Referem-se a todos os direitos dos traba- } \\
\text { lhadores como: remuneração justa, capaz } \\
\text { de satisfazer e garantir ao trabalhador e } \\
\text { família uma vida digna; repouso e ao lazer; } \\
\text { alimentação, saúde, serviço social, médi- } \\
\text { co; seguridade em caso de desemprego; } \\
\text { previdência, etc. }\end{array}$ \\
\hline Econômicos & $\begin{array}{l}\text { Os Direitos Sociais Econômicos e } \\
\text { Culturais surgiram das lutas } \\
\text { campesinas e do operariado. }\end{array}$ & $\begin{array}{l}\text { Assegurar as liber- } \\
\text { dades por meio do } \\
\text { Estado }\end{array}$ & $\begin{array}{l}\text { Assinalam o direito se organizar em sindi- } \\
\text { catos em defesa de seus interesses, à } \\
\text { propriedade individual ou coletiva; direito } \\
\text { ao trabalho, justa remuneração entre } \\
\text { homens e mulheres, direito à greve, férias } \\
\text { remuneradas, etc. }\end{array}$ \\
\hline
\end{tabular}




\begin{tabular}{|l|l|l|l|} 
& $\begin{array}{l}\text { Os Direitos Culturais, conforme já } \\
\text { mencionado, acompanham o } \\
\text { bojo das mudanças "revoluções } \\
\text { culturais" e "Virada Cultural", } \\
\text { refletindo em vários instrumen- } \\
\text { tos internacionais. }\end{array}$ & $\begin{array}{l}\text { Assegurar as liber- } \\
\text { dades por meio do } \\
\text { Estado }\end{array}$ & $\begin{array}{l}\text { Direitos culturais assegurados aos indiví- } \\
\text { duos: Direito de participar da vida cultural } \\
\text { da comunidade, de usufruir das artes, de } \\
\text { participar do progresso científico e dos } \\
\text { seus benefícios gerados. Constituem } \\
\text { também Direitos Culturais: direito autoral, } \\
\text { a livre criação, à difusão dos bens cultu- } \\
\text { rais. Direitos culturais assegurados aos } \\
\text { povos: Direito à identidade cultural e o } \\
\text { direito-dever de cooperação internacional. }\end{array}$ \\
\hline $\begin{array}{l}\text { Difusos } \\
\text { Transindivi- } \\
\text { duais }\end{array}$ & $\begin{array}{l}\text { Originários dos movimentos } \\
\text { sociais ocorridos em 1960 e 1970 } \\
\text { (ambientalistas, feministas, cultu- } \\
\text { rais) }\end{array}$ & $\begin{array}{l}\text { Requerem a presen- } \\
\text { ça das instituições } \\
\text { estatais, tribunais e } \\
\text { ministérios públicos }\end{array}$ & $\begin{array}{l}\text { Relacionam-se às condições de vida no } \\
\text { planeta, como o direito ao meio ambiente } \\
\text { saudável, à qualidade de vida, à paz inter- } \\
\text { nacional, dos consumidores e Direito ao } \\
\text { Desenvolvimento. }\end{array}$ \\
\hline
\end{tabular}

Adaptado de M eyer-Bisch; Bidault (2014, p.18); Mata-M achado (2007, p. 1-15); Piovesao (2002, p.3-7).

Assim, é importante compreender que os direitos civis surgiram contra os Estados absolutistas; os direitos políticos, no século de XIX; e os direitos econômicos, sociais e culturais, conectadas às lutas camponesas, do operariado e dos movimentos socialistas. Há também os direitos difusos ou transindividuais, os mais recentes. Estes se relacionam à qualidade de vida, ambiente saudável, paz mundial, etc.

Os direitos civis e políticos se relacionam aos princípios de Liberdade e tem foco na proteção do indivíduo contra o Estado. Os Direitos Sociais, Econômicos e Culturais se relacionam aos princípios de Igualdade e requerem prestação do Estado. Ambos foram pactuados no mesmo ano, 1966, mas em documentos separados: o Pacto Internacional pelos Direitos Civis e Políticos e o Pacto Internacional pelos Direitos Sociais, Econômicos e Culturais. Os Pactos de 1966 demonstram o pano de fundo histórico e ideológico dos direitos mencionados quando as

potências ocidentais insistiam no reconhecimento, tão só, das liberdades individuais clássicas, protetores da pessoa humana contra os abusos e interferências dos órgãos estatais na vida privada. Já ospaíses do bloco comunista e os jovens países africanos preferiam pôr em destaque os direitos sociais e econômicos, que têm por objeto políticas públicas de apoio aos grupos ou classes desfavorecidas, deixando na sombra as liberdades individuais. Decidiu-se, por isso, separar essas duas séries de direitos em tratados distintos, limitando-se a atuação fiscalizadora do Comitê de Direitos Humanos unicamente aos direitos civis e políticos, e declarando-se que os direitos que têm por objeto programas de ação estatal seriam realizados progressivamente, "até o máximo dos recursos disponíveis" de cada Estado (Pacto sobre Direitos Econômicos, Sociais e Culturais, art. $2^{\circ}$, alínea I) (COM PARATO, 2013, p. 292).

0 agrupamento de direitos é sugerido por diversos autores como "gerações", sendo a primeira geração a dos direitos advindos do liberalismo (Direitos Civis e Políti- 
cos); a segunda geração é procedente dos movimentos socialistas (Direitos Sociais, Econômicos e Culturais), e a terceira aponta para a solidariedade internacional (Direitos Difusos e Transindividuais). A classificação em gerações é bastante criticada, haja vista que a evolução dos direitos não se dá pela superação e dispensa de direitos anteriores por novos direitos, mas pela acumulação, pelo acréscimo destes. Não se trata de substituição, mas da soma de direitos.

Assim, Souza (2012, p. 56) indica que a classificação destas normatizações é expressada mais apropriadamente como "dimensões", sendo que a primeira dimensão equivale aos direitos de liberdade, objetivamente os Civis e Políticos; a segunda dimensão corresponde aos direitos de igualdade e se referem aos Direitos Econômicos, Sociais e Culturais; a terceira satisfaz os direitos difusos e transindividuais, não se detém ao indivíduo ou a coletividade, sedimentam-se na solidariedade; os direitos de quarta dimensão indicam "a verdadeira universalidade" e representam a globalização dos direitos fundamentais.

Mais que formas de categorizar, estes agrupamentos revelam várias tensões. Os Direitos Humanos têm origens diferentes, carregam a trajetória de transformação do modelo liberal para o social de Estado, e por isso, entre si, recebem tratamentos distintos, o que pode explicar a priorização de alguns direitos em relação a outros. $\mathrm{Na}$ perspectiva de Piovesan (2012, p. 8), existem duas fases dos Direitos Humanos que estão centradas na identificação dos sujeitos de direito: a primeira, marcada pelos horrores do nazismo, pune o temor da diferença, e a segunda, o direito à diferença e à diversidade. Para a autora "ao lado do direito à igualdade, surge, também, como direito fundamental o direito à diferença" (Id. bid.), o que assegura aos sujeitos, o tratamento especializado na garantia de direitos, principalmente focado nas populações mais vulneráveis e suas especificidades à exemplo de mulheres, afrodescendentes, indígenas, deficientes, migrantes, etc. É sobre estes grupos que recaem as maiores violações dos direitos de "segunda dimensão" ao mesmo tempo em que "muitas estratégias de desenvolvimentos revelam-se inadequadas por ignorância desses mesmos direitos [os culturais, em especial], constatamos que a universalidade e a indivisibilidade dos direitos humanos padecem sempre com a marginalização dos direitos culturais" (GRUPO DE FRIBURGO apud MEYER-BISCH; BIDAULT, 2014, p. 13) .

A Declaração sobre o Direito ao Desenvolvimento (1986) é resultado da nãoacionalidade dos direitos sociais, culturais e econômicos, por motivos ideológicos e da necessidade de reafirmar os sujeitos do Desenvolvimento. Neste panorama, e como consequência das polaridades internacionais (países do Leste/Oeste e Norte/Sul), "surge o empenho do Terceiro Mundo de elaborar uma identidade cultural própria, propondo direitos de identidade cultural coletiva, como direito ao desenvolvimento" (LAFER apud PIOVESAN, 2002, p. 5). Esta Declaração preconiza a universalidade, a indivisibilidade dos direitos, a participação social, as necessidades básicas de justiça social e a admissão de políticas públicas nacionais com vistas ao desenvolvimento, de acordo com Piovesan (2002, p. 5). A autora destaca o artigo 2ํ da Declaração sobre 0 
Desenvolvimento, considerando que: "A pessoa é o sujeito central do desenvolvimento e deve ser ativa participante e beneficiária do direito ao desenvolvimento" (PIOVESAN, 2002, p. 5). De acordo com a autora, globaliza-se uma demanda ética e solidária para consecução do Desenvolvimento focada na vida das pessoas, em especial, as mais vulneráveis.

Na linha de Piovesan (op. cit.), na apresentação de M eyer-Bisch e Bidault (2014, p. 12), Teixeira Coelho evidencia que o maior direito é o direito à vida, e posiciona a cultura como inerente à vida, numa relação de pertencimento tal que não existe um sem o outro, reforçando a indivisibilidade e a universalidade:

Mas o direito à vida sem cultura não é nada. Não que seja pouco: não é nada. 0 homem é homem porque faz o que nenhum outro ser vivo faz: contar histórias e se contar histórias. Alguns ainda lembram a definição de Aristóteles do homem como zoon politikon, animal político, para fazer crer que a marca do homem é a política. 0 conceito de Aristóteles só fica em pé se, primeiro, for lembrado que política é o que diz respeito à cidade e que a política é uma narrativa, uma história. É o que permite ao ser humano a cultura. Sem cultura, não há ser humano, portanto não há vida humana (COELHO, 2014, p. 12).

Para Sen (2000, p. 10-11), as pessoas, como fim último do Desenvolvimento, devem desempenhar o papel de agente, já que são os beneficiários das estratégias implementadas, de tal forma que o desenvolvimento deve ser concebido como expansão das liberdades reais que as pessoas possam desfrutar. Assim, com oportunidades sociais adequadas, os indivíduos podem moldar seus destinos e cooperar entre si, e não precisam ser vistos, sobretudo, "como beneficiários passivos de engenhosos programas de desenvolvimento" (op. cit., p. 26).

Sen (1998, p. 4) observa que a cultura participa do Desenvolvimento de três formas: a) como constituinte básico e inseparável do Desenvolvimento geral, visto que privar as pessoas de entender e cultivar a criatividade é um obstáculo ao Desenvolvimento. Dessa forma, a educação é uma parte essencial do Desenvolvimento cultural; b) na valoração: a atribuição de valores é influenciada pela cultura. Ao crescimento econômico faltam elementos externos significativos, por exemplo, sobre as coisas que valorizamos intrinsecamente, as quais somente a cultura é capaz de refletir; e c) segundo seu papel instrumental: as metas econômicas devem ser rigidamente influenciadas pela natureza da cultura e pelo comportamento ético. Isso se aplica não só para promover o crescimento econômico, mas em outras alterações, como a melhoria na qualidade de vida associada com o Desenvolvimento num sentido mais amplo.

0 Direito ao Desenvolvimento parece responder a este intento à medida em que concebe 0 desenvolvimento de forma multidimensional, considerando indissociáveis, neste processo, os enfoques políticos, sociais, econômicos e culturais, "dentro dos quais os direitos humanos podem ser plenamente realizados" (SOUZA, 2012, p. 53), propiciando "a eliminação de privações de liberdade que limitam as escolhas e as 0- 
portunidades das pessoas de exercer ponderadamente sua condição de agente" (SEN, 2000, p. 10). De tal forma, os Direitos Humanos aparecem como um guião que deve ser alavancado cada vez mais pela cooperação internacional, pela participação e pela justiça social. Estes são os aspectos de maior destaque da Declaração sobre Direito ao Desenvolvimento.

Mas a perspectiva da efetivação dos Direitos Humanos como condição para o Desenvolvimento não passa sem críticas, a maior parte delas enfatiza os aspectos ocidentais marcados na construção dos direitos. Santos (1997, p. 107) afirma por isso, que "a política dos direitos humanos é basicamente uma política cultural". Nela a acepção de dignidade humana é única e universal. A universalidade enquanto pressuposto ocidental também é arguida por Sen (2000). 0 autor denomina essa linha de argumentação de 'crítica cultural' pela qual entra em análise a autoridade moral dos Direitos Humanos, cuja universalidade dos valores éticos pode ser questionada, pois algumas culturas podem não considerar "os direitos particularmente valiosos em comparação com outras virtudes ou qualidades preponderantes" (Op. cit., p. 263). Em outras palavras, a ideia de universalidade supõe que todas as culturas compreendem igualmente a dignidade humana e se fundam no mesmo sistema de valoração ética e moral. Isto sugere a imposição da ideia de dignidade do ocidente como universal.

Santos (1997, p. 113-118) ainda assinala que o imperialismo cultural e o epistemicídio integram a trajetória histórica da modernidade ocidental. A própria Declaração de 1948 foi elaborada sem a maioria dos povos, e o reflexo disso pode ser observado: na "dicotomia rígida entre indivíduo e sociedade, tornando-se assim vulnerável ao individualismo possessivo, ao narcisismo, à alienação e a anomia" (Op. cit., p. 118); e na "dificuldade de aceitar coletivos de grupos sociais ou povos, ou comunidade como locus de solidariedade concreta, campo político dominado por política horizontal" (Op. cit., p. 117). A 'crítica cultural' do autor ressalta não só os aspectos ocidentais como também liberais dos Direitos Humanos. De forma que, o direito à propriedade vigorou por muito tempo como único direito econômico, além do que existe uma insistente prioridade concedida aos direitos civis e políticos em desfavor dos demais, sustentando exclusivamente os direitos individuais.

Tal concepção guarda relação com a tensão dialética entre Estado e Sociedade. De acordo com Santos (op. cit., p. 106), enquanto a primeira geração de direitos busca defender o indivíduo contra o Estado, a segunda e a terceira geração assevera ao Estado, as implicações de responsável garantidor dos Direitos Humanos. De forma que o Estado moderno, embora se apresente como minimalista, ao produzir leis de maneira ilimitada, faz-se um potencial Estado maximalista.

Neste processo, estão engendradas, além da tensão entre o Estado-Regulador e 0 Estado-Providência, a crise de emancipação representada pela crise do paradigma do socialismo como transformação radical. Em virtude disso, as forças progressistas apelam aos Direitos Humanos como linguagem de emancipação (op. cit., p. 105-106). 
Como decorrência, é possível observar, ao longo do tempo, uma mudança de prioridades que posicionou os Direitos Humanos como uma literatura importante pertinente ao Desenvolvimento (SEN, 2000) e um varadouro para a igualdade jurídica de grupos marginalizados, excluídos, minorias, etc. De forma que, é recorrente o constrangimento internacional apresentar-se como única forma de punição dos Estados e voz destes grupos. Neste sentido, é através dos Direitos Humanos e da "sociedade civil global" (SANTOS, 1997, p. 105-106) que se propala a defesa dos grupos oprimidos, desenhando propostas contra-hegemônicas, não-ocidentais e interculturais na história destes direitos, bem como dividindo o protagonismo dos Estados.

Dessa maneira, ao mesmo tempo que concebemos que "os direitos humanos assentam-se em pressupostos específicos" (op. cit., p. 107), é necessário esclarecer também que esses direitos: são históricos (BOBBIO apud MATA-M ACHADO, 2007, p. 2); estão em constante construção; são cumulativos de ampliação qualitativa e quantitativa (SOUZA, 2012, p.56); indivisíveis e universais, e combinam valores do discurso liberal e do social (PIOVESAN, 2002, p. 1-14); fortalecem a noção de cidadania mundial e de uma sociedade civil internacional (MATA-MACHADO, 2007, p. 14); e condiciona os poderes públicos na formulação de políticas e normativas (SOUZA, 2012, p. 58); é possível afirmar que os Direitos Humanos constituem um instrumento irrecusável para a garantia da dignidade, da liberdade e do desenvolvimento integral.

Para tanto, considerar as especificidades locais pode ser a chave para o que Santos (1997, p. 105-124) defende como o multiculturalismo dos Direitos Humanos capaz de fazer frente aos aspectos exclusivamente ocidentais. Por isso, os marcos internacionais sobre direitos culturais e sobre diversidade cultural tem um papel fundamental não só pela proteção contra ofensiva dos mercados sobre as culturas locais, como também no fortalecimento das identidades, modos de vida, sistemas de valoração, para as vozes das minorias, os quais certamente incidem na democratização do sistema internacional de Direitos Humanos. A cultura está na centralidade de uma plataforma emancipatória baseada no exercício e na garantia plena dos direitos humanos, portanto. Reconhecer a diversidade cultural é indispensável ao mundo contemporâneo.

O contexto e as contribuições epistemológicas mencionadas incidiram nos paradigmas contemporâneos de Desenvolvimento. Como expressão disso, os tratados internacionais se lançam a multidimensionalidade do Desenvolvimento considerando a Cultura como condição sine qua non de formação da vida humana e, portanto, essencial para efetivação do Direito ao Desenvolvimento. Neste sentido, o fortalecimento e a afirmação dos Direitos Culturais e da diversidade cultural, a partir de Políticas de Cultura, se impõem como um desafio e uma perspectiva do Desenvolvimento. 


\section{CONSTRUÇÕES HISTÓRICAS DE POLÍTICAS DE CULTURA E DESENVOLVIMENTO NO ESTADO DO AM APÁ}

O tema da diversidade cultural avançou sobremaneira constituindo denso arcabouço normativo internacional e orientando as Políticas Públicas no sentido de conduzir, a partir das regiões, as Políticas de Desenvolvimento, ao considerar a proteção e o fomento das culturas locais como indispensáveis nesta formulação. Porém, é pertinente destacar que as disputas mencionadas no campo dos Direitos Humanos e, em especial, acerca dos Direitos Culturais, permanecem na tensão existente entre os agentes da política cultural e a percepção de atuação do Estado, de modo que:

Quando falamos em política cultural, não estamos nos referindo apenas a uma relação administrativa por parte do governo sobre a cultura, mas, sim, como situa Eduardo Nivon Bolán, ao "interesse e a tensão existente entre o poder político e o campo da cultura e da arte" (BOLÁN, 2006, p. 54). A política cultural resulta das disputas e do jogo político no âmbito da cultura. A definição do "quê", "quem", "como" e "para quê" de uma política cultural depende das estruturas de poder e das relações sociais que vigoram em determinado momento em um espaço específico, seja um município, seja um estado, seja uma nação (BARBALHO, 2013, p. 9).

Isto permite afirmar que as disputas históricas, em âmbito internacional para o reconhecimento destes direitos, estendem-se ao longo do tempo e dos espaços, resultando num "jogo político" para definição de responsabilidades do Estado e demais agentes. Uma forma de observar quais os interesses e tensões entre o poder político e o campo da Cultura e da Arte, demonstrando, portanto, que as disputas pelo reconhecimento dos direitos culturais ainda se prolongam, estão manifestadamente nas legislações e na efetivação das Políticas Culturais localmente, ou mesmo, na inexistência delas.

O Amapá é um estado com 142,828, $523 \mathrm{Km}^{2}$, localizado à margem esquerda do rio Amazonas, ao norte do Brasil, numa região de fronteira internacional limitada ao norte pela Guiana Francesa e ao sul pelo Pará. Um dos estados mais jovens da federação, o Amapá foi destacado do Pará em 1943, pelo Decreto-lei no 5.812, de 13 de Setembro, quando o governo federal criou o Território Federal do Amapá e transformado em estado através da Assembleia Nacional Constituinte, em 1988. Do ponto de vista da diversidade cultural, o estado tem uma história de ocupação semelhante a do restante do país, com a presença de indígenas, a chegada de europeus - principalmente portugueses, espanhóis e franceses - e africanos, a partir do processo de colonização.

Atualmente, o Amapá conta com uma área de cerca de 142.828, 523 km2 (IBGE, 2015), do qual 73,74\% de seu território são dedicados às Unidades de Conservação e Terras Indígenas (CHELALA, 2008, p. 126). São 09 grupos étnicos - Galibi Kalina, Galibi 
Marworno, Palikur, Karipuna, Waiãpi, Aparai, Waiana, Tiriyos e Kaxuyana ${ }^{1}$ - que ocupam uma faixa de terras a qual se estende do Amapá ao Norte do Pará e são atendidos pela Fundação Nacional do Índio -FUNAl, através superintendência do Amapá. A maioria da população indígena do estado se concentra nos municípios de Oiapoque (5.569), Pedra Branca do Amapari (883) e Macapá (723), totalizando 7.394 indígenas distribuídos em suas terras indígenas (IBGE, Censo, 2010).

A população parda autodeclarada brasileira representa $43,1 \%$. Na Região Norte, essa proporção foi de $66,9 \%$. Já a população preta autodeclarada corresponde a 7,6\% nacionalmente, sendo o Nordeste, a região com maior percentagem, 9,5\% (IBGE, Censo, 2010). No Amapá o percentual de pardos e pretos alcança 73,9\%, configurando, ao lado do Pará $(76,8 \%)$, Bahia (76,3\%) e Maranhão (76,2\%), a quarta proporção mais elevada destes autodeclarados no país (Id. Bid.). Existem 28 comunidades quilombolas certificadas pela Fundação Cultural Palmares (FCP) (SUPERTI ; SILVA, 2015), 04 tituladas e 26 em fase de regularização fundiária junto ao INCRA. Superti e Silva (2015), resumem a história dessas demarcações relacionando-os ao desempenho dos movimentos sociais negros de abrangência nacional:

No Amapá, acompanhando o movimento nacional, essa luta ganhou força pela atuação dos movimentos sociais negros, especialmente por meio da Coordenação Estadual das Comunidades Quilombolas do Amapá (CONAQ-AP). Segundo Silva (2012), em 2011, 138 comunidades quilombolas haviam sido identificadas em todo estado. Destas, até 2013 , ano da realização desta pesquisa, 28 comunidades ( $M$ apa 1 ) tinham certidão de autoreconhecimento emitida pela FCP e, entre elas, 04 comunidades conseguiram o título de propriedade de seu território emitidos pelo Instituto Nacional de Colonização e Reforma Agrária (INCRA), são elas: Curiaú, Mel da Pedreira, Conceição do Macacoari e São Raimundo do Pirativa. (SUPERTI; SILVA, 2015).

Este estado, que apresenta forte potencial para o turismo ecológico e cultural, apresenta uma estrutura institucional com órgãos gestores específicos para as políticas sociais destinadas aos povos tradicionais indígenas e afro-brasileiros. São duas secretarias vinculadas diretamente ao gabinete do governador no organograma: a Secretaria Extraordinária de Povos Indígenas (SEPI) e a Secretária Extraordinária de Afrodescendentes (SEAFRO). Estas não têm orçamento específico, funcionando mais como articuladoras junto à outras secretarias. Também não é muito frequente, o fomento às iniciativas culturais indígenas, através da Secretaria Estadual de Cultura (SECULT-AP), conforme é possível verificar através dos convênios discriminados no

\footnotetext{
${ }^{1}$ Os indígenas do Norte do Pará (Waiana, Tiriyos e Kaxuyana) que vivem no Parque Indígena do Tumucumaque são atendidos pelos equipamentos sociais do Amapá, numa área correspondente a jurisprudência da FUNAI/AP, transitam com frequência entre os dois estados, bem como nos países fronteiriços como Suriname e Guiana Francesa. Estes povos também são atendidos pela Secretaria Extraordinária dos Povos Indígenas do Amapá (SEPI-AP).
} 
Portal da Transparência do Governo do Estado do Amapá ${ }^{2}$. Entre os anos 2008 e $2015^{3}$, constam somente 05 atividades indígenas com o apoio do órgão gestor de Cultura. Mas estes dados ainda refletem uma parte reduzida de um cenário muito mais complexo que envolve a atuação e ausência de outros órgãos e esferas públicas.

\subsection{A articulação do Amapá ao Sistema Nacional de Cultura (SNC)}

O Sistema Nacional de Cultura (SNC), instituído com a Proposta de Emenda Constitucional - PEC no 416/2005, tem como princípio a diversidade cultural, sugerindo que populações historicamente ameaçadas em seus direitos culturais participam prioritariamente nas estratégias de Desenvolvimento Regional já que é a partir das diferenças na/da região que a diversidade se expõe. A articulação iniciada em 2003, surge como uma necessidade em resposta à instabilidade, pouca institucionalidade e efetividade das Políticas Públicas de cultura no Brasil. Assim, neste ano, são iniciados os debates nacionais acerca dos Sistemas de Cultura e em 2010, em virtude da realização da II Conferência Nacional de Cultura, a proposta é aprovada com primazia. A partir disso, os entes federados inauguram os processos de formulação de seus sistemas visando a integração à Política Nacional de Cultura.

O SNC estabelece que os entes federados (União, Estados e M unicípios), interajam de forma articulada para o planejamento e gestão da Política Cultural com a participação da sociedade civil, tendo por objetivo promover o Desenvolvimento Humano, Social e Econômico com exercício pleno dos Direitos Culturais. Este Sistema aponta para:

a) O papel do Estado na Cultura, o qual deve atuar sempre considerando em primeiro plano o interesse público e o respeito à diversidade cultural (Artigos 215 e 216 da Constituição Federal), cabendo-Ihe a formulação e execução das Políticas Públicas de Cultura, o planejamento e fomento as atividades culturais, a preservação e valorização do patrimônio cultural material e imaterial do país, os marcos regulatórios para a economia da cultura, a garantia do acesso universal aos bens e serviços culturais e a proteção e promoção a diversidade das expressões culturais;

b) Os Direitos Culturais como plataforma de sustentação: baseando-se nos acordos internacionais no âmbito da ONU, como o direito à identidade e à diversidade cultural, direito à participação na vida cultural (livre criação e expressão, livre acesso, livre difusão, livre participação nas decisões de política cultural), o direito autoral e 0 direito ao intercâmbio cultural nacional e internacional;

c) A tridimensionalidade da cultura: considerando que a mesma tem uma dimensão simbólica, a qual se refere a capacidade que todo ser humano possui de criar sím-

\footnotetext{
${ }^{2}$ AM APÁ. Portal da Transparência do Estado do Amapá, 2015.

${ }^{3}$ Tomou-se como referência este intervalo, pois só existem dados referentes aos convênios realizados com a SECULT-AP, a partir do ano de 2008, período em que a Fundação de Estado da Cultura do Amapá (FUNDECAP) é transformada em Secretaria de Cultura do Amapá (SECULT-AP).
}

PRACS: Revista Eletrônica de Humanidades do Curso de Ciências Sociais da UNIFAP 
bolos expressando práticas culturais distintas (idiomas, costumes, culinária, modos de vestir, crenças, criações tecnológicas, arquitetônicas, etc), e linguagens artísticas diversas (teatro, música, artes visuais, dança, literatura, circo, etc); a dimensão cidadã, que denota a cultura como um direito básico do cidadão; e a dimensão econômica, que pauta a cultura como vetor de desenvolvimento econômico, socialmente justo e sustentável e alinhado ao mundo contemporâneo.

Para tanto, o SNC é constituído de componentes obrigatórios (os Órgãos Gestores da Cultura, os Conselhos de Política Cultural, as Conferências de Cultura, os Planos de Cultura, os Sistemas de Financiamento à Cultura) e facultativos (Comissões de Intergestores, Sistemas de Informações e Indicadores Culturais, Programas de Formação na área da Cultura e os Sistemas Setoriais de Cultura). De tal forma que o Plano Nacional de Cultura, instituído pela Lei № 12.343, de 02 de dezembro de 2010, apresenta como primeira meta a ser atingida até 2020 , a institucionalização e implementação do Sistema descrito em todos os estados e em mais da metade dos municípios. "M eta-1: Sistema Nacional de Cultura institucionalizado e implementado, com $100 \%$ das Unidades da Federação (UF) e $60 \%$ dos municípios com sistemas de cultura institucionalizados e implementados" (M inC, 2012, p. 22).

Esta percepção sobre um sistema institucional para 0 atendimento às demandas referentes às Políticas Públicas Culturais, reforça as relações intergovernamentais, segundo um modelo tripartite de federalismo, advindo com a Constituição Federal de 1988. Este modelo visa distribuir competência, descentralizar decisões, estimular a participação de coletividades locais - sem as quais não é possível a proteção e promoção da diversidade -, aumentando o controle social e mantendo a autonomia administrativa e fiscal.

Diante de tais obrigatoriedades, o Amapá se manifesta acompanhando, mesmo com algum atraso, as principais transformações institucionais e marcos regulatórios relacionados à Política Cultural estabelecida a partir do Governo de Luis Inácio Lula da Silva. A Secretaria de Estado de Cultura do Amapá (SECULT-AP) é o órgão gestor específico, criada pelo Decreto Lei no 1.073 de 02 de março de 2007. Dos anos 2002 a 2015, estiveram à frente da pasta 06 gestores. A Secretaria, foi antes uma autarquia: a Fundação de Estado da Cultura do Amapá (FUNDECAP), instituída pela Lei no 0101, de 02 de setembro de 1993, cujo quadro funcional, orçamento e políticas de gestão, não se alteraram muito quando da transformação em Secretaria.

De acordo om o Portal da Transparência do Estado do Amapá, o quadro funcional totaliza 126 servidores, sendo formado por $46 \%$ de cargos comissionados, $38 \%$ contratos administrativos, 06 servidores federais cedidos e apenas 14 de servidores estaduais concursados para atuarem no órgão $0^{4}$. A Secretaria não possui prédio, sendo constante 0 deslocamento de pessoal e acervos para imóveis locados, seja pela mudança de governadores, seja pela inadequação predial. Tal qual os prédios, os servidores da Secretaria cuja maioria é de comissionados e contratados (84\%), também

${ }^{4}$ AM APÁ. Portal da Transparência do Estado do Amapá, 2015.

PRACS: Revista Eletrônica de Humanidades do Curso de Ciências Sociais da UNIFAP 
são substituídos a cada nova gestão. Esta instabilidade que se reflete na ausência de instalações físicas e de quadro funcional específico mais perene, sugere a descontinuidade das Políticas Culturais, com a perda de referências, informações e com disputas entre as gestões governamentais que se sucedem.

Assim, embora cumpra-se com a obrigatoriedade de existência desse componente (órgão gestor específico) previsto no SNC, a descontinuidade das Políticas Culturais fazem do componente apenas uma resposta ao aparelho burocrático estatal. Isso se reflete na distribuição dos recursos destinados à SECULT-AP, os quais solicitam suplementação frequentemente, subsidiam majoritariamente eventos e não dispõe de mecanismos de acesso assegurados.

Em comparação, o montante de recursos públicos gastos pelo Governo Federal na função Cultura ${ }^{5}$, que passou de $0,02 \%$ do Produto Interno Bruto (PIB) em 2000 para 0,036\%, em 2010 - representando um crescimento de 80\% em 10 anos, conforme as M etas do Plano Nacional de Cultura, (M inC, 2011, p. 95) -, o Amapá demonstra uma realidade não muito animadora, já que os valores acrescidos ano a ano relativos à função cultura ${ }^{6}$ não acompanharam o crescimento do PIB estadual, tampouco a curva de crescimento referente à função cultura da União.

O gráfico abaixo demonstra que, embora o PIB do Amapá acumule variações positivas - ainda que baixas, o que o posiciona como antepenúltimo na economia nacional $^{7}$-, o Orçamento Geral e a Função Cultura do estado possuem oscilações muito distintas. 0 ano de 2008 apresenta uma variação acentuada na Função Cultura. Este ano coincide com a transformação da autarquia FUNDECAP em Secretaria de Estado, SECULT-AP. Outro dado importante se refere a variação negativa no Orçamento Geral em 2009, na ordem de 22\%, acompanhada pela Função Cultura no ano posterior, embora nos dois períodos a linha do PIB-AP permaneça estável e em variação positiva, ainda que tímida.

5 Tramita no Congresso Nacional, a proposta de Emenda constitucional, PEC no 150/2003, que estabelece 0 piso constitucional para investimentos em Cultura e vincula os orçamentos nas três esferas de governo: municipal, estadual e federal, sendo respectivamente, $1 \%, 1,5 \%$ e $2 \%$.

${ }^{6}$ Foram consideradas as despesas liquidadas, haja vista que 0 empenho (reserva do orçamento), neste caso, deva ser efetivamente destinado àquela despesa não poder ser mais anulado.

${ }^{7}$ Conforme a pesquisa Contas Regionais do Brasil 2013: Produto Interno Bruto - PIB e participação das Regiões e Unidades da Federação, IBGE. Consultado em 28 de dezembro de 2015. 
Gráfico 1 - Variação percentual de PIB, Orçamento Geral e Função Cultura do Amapá a partir de dados do Tesouro Nacional e Portal Transparência do Amapá

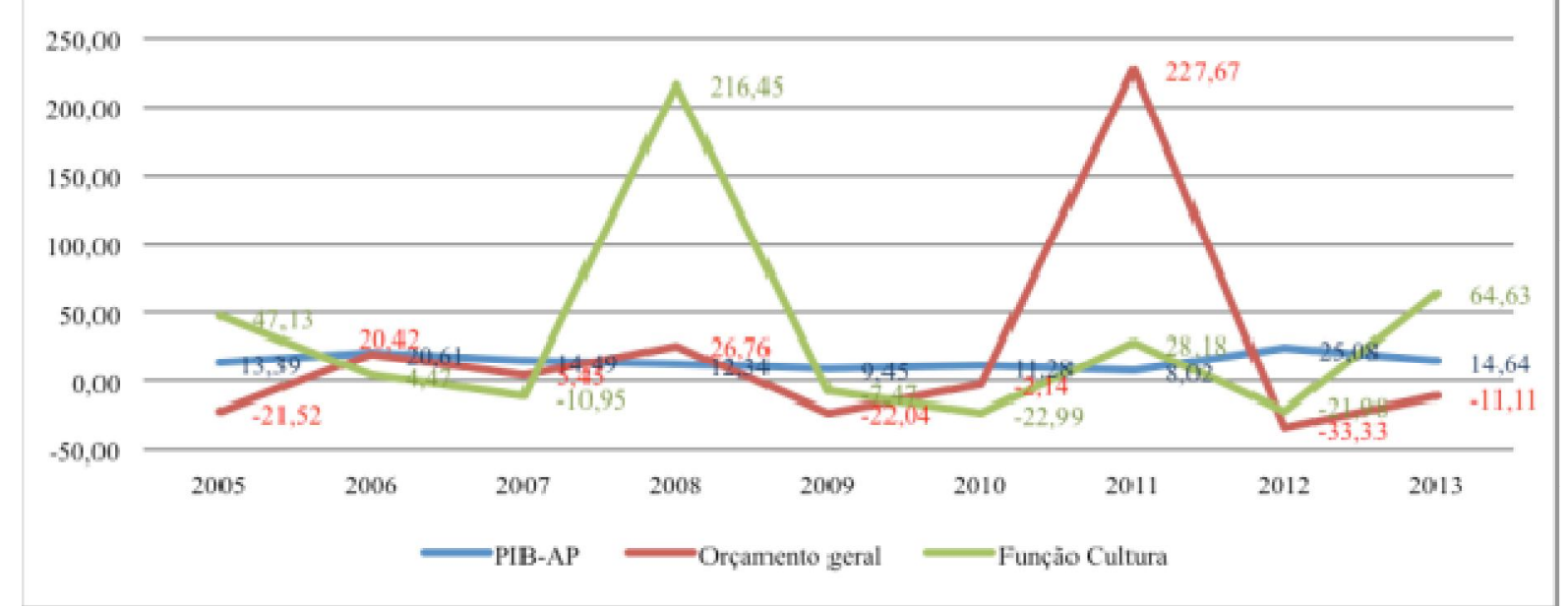

Fonte: Quintas (2016).

Com um orçamento médio de $\mathrm{R} \$ 15,2$ milhões (com referência nas despesas liquidadas entre os anos de 2010 a 2015), a SECULT-AP é uma das Secretarias com o menor orçamento do Amapá, realidade também compartilhada por outros estados da Federação. Deste recurso, quase a totalidade se destina a execução de eventos por meio de subvenções ${ }^{8}$ e outra parte significativa, para contratação de serviços de terceiros como estruturas de sonorização e palco. Estas ações se caracterizam pela realização de eventos a preços populares ou gratuitos, sem finalidade lucrativa. A maior parte dos eventos são de caráter artístico ou festas tradicionais (como festas juninas, festas de santo, de Marabaixo e das comunidades quilombolas) havendo prevalência de duas linguagens: 0 teatro e a música.

O Fundo de Cultura, como um dos componentes obrigatórios do SNC, tem natureza contábil e é um dos principais mecanismos de financiamento de programas, projetos e ações culturais. Em regime de colaboração entre os entes federados, ele permite que haja transferência fundo a fundo, isto é, o repasse do Fundo de Cultura da União aos demais entes federados (estado ou municípios) se somando aos outros recursos que o compõem. Os Fundos de Cultura devem priorizar seleções públicas que contém comissões representativas habilitadas a avaliar o mérito artístico-cultural das propostas submetidas.

O Fundo Nacional de Cultural foi instituído pela Lei ำ 8.313, de 23 de dezembro de 1991, contando com recursos na forma de apoio a fundo perdido ou de empréstimos reembolsáveis. No Amapá, o Fundo Estadual de Arte e Cultura do Amapá foi criado em 2004, por meio da Lei no 1520 de 16 de novembro de 2010. Esta lei determina que os recursos do fundo seriam provenientes do orçamento da Fundação Estadual da Cultura do Amapá-FUNDECAP com valor nunca inferior a $\mathrm{R} \$ 300.000,00$ (trezen-

${ }^{8}$ Considera-se subvenção: transferências destinadas a cobrir despesas de custeio das entidades beneficiadas, distinguindo-se como subvenções sociais, as que se destinem a instituições públicas ou privadas de caráter assistencial ou cultural, sem finalidade lucrativa", conforme a Lei Federal no 4.320 de 17 de março de 1964. 
tos mil reais). Além de estar vinculado à FUNDECAP em seu texto original (2004), a qual foi extinta e sucedida em suas funções públicas pela SECULT-AP, em 2007, devido a ausência de regulamentação, o fundo nunca foi operacionalizado, estando submetido à análise jurídica da Procuradoria Geral do Estado do Amapá (PROG) devido questões tributárias há pelo menos 4 anos.

Também participa do fomento às iniciativas artísticas e culturais, a Lei Estadual de Incentivo à Cultura. Esta, em seus mais de 10 anos de existência, fomentou apenas um projeto - a revista 0 Pavio, em 2007. A publicação teve 4 edições e como único patrocinador uma rede local de lojas de móveis e eletrodomésticos. A Lei Estadual de Incentivo à Cultura sofreu alterações (Lei ํo 0912, de 10 de agosto de 2005), foi regulamentada pelo Decreto no 4823, de 28 de outubro de 2005, e, após estas mudanças, jamais foi acionada novamente para o fomento de projetos culturais via dedução do Imposto sobre a Circulação de Mercadorias e Serviços (ICMS).

De tal modo, assim como o Fundo, a Lei Estadual de Incentivo à Cultura, enquanto mecanismo de fomento, para além dos parcos recursos da SECULT-AP, também não está em funcionamento. Esta inoperância das leis de Cultura estadual, sugerem que, embora normativamente resguardada, através da criação de estruturas determinadas em leis maiores - as leis federais -, a Política Cultural no Amapá carece de efetividade das normas e regulamentação das estruturas administrativas e dos mecanismos de fomento, sob pena de nunca sequer passarem de letra morta, antes mesmo de figurarem a vivacidade e a potência a que pretendem.

Em relação ao apoio através da "Lei Rouanet" (Lei no 8.313 de 23 de dezembro de 1991), o Amapá figura entre os estados com o menor número de projetos, 66 ao todo, ao lado de Roraima (23) e Sergipe (96), entre os de 1996 e 2015. 0 reduzido número de projetos apoiados na região Norte revela a enorme discrepância no acesso e distribuição destes recursos quando comparado ao acesso da região sudeste, à exemplo dos estados de Minas Gerais, Rio de Janeiro e São Paulo, que se somados, resultam em $1 / 3$ de todos os apoios já concedidos às UF's.

Esta lógica de concentração de recursos públicos e investimentos privados, no caso da Cultura segue a mesma lógica da concentração econômica do país. Os problemas de distribuição não se restringem aos projetos apoiados através da "Lei Rouanet", cuja decisão do patrocínio é da empresa - como também se estende aos editais e programas federais. A mesma lógica de concentração se reproduz no Amapá, quando se observa a quantidade de convênios executados na capital, média de $78 \%$, entre os anos de 2010 e 2015.

É um desafio da política de cultura não se deixar orientar pela estrutura macroeconômica e, enquanto política pública de promoção e proteção da diversidade das expressões culturais, reunir estratégias para corrigir distorções sociais e impedir discriminações que possibilitem ao país, à região e ao estado se ver na sua diversidade.

Ainda em 2005, é criado outro dos componentes constitutivos obrigatórios do Sistema de Cultura Estadual, o Conselho Estadual de Cultura (CONSEC), por meio da Lei 
no 0911/2005. O Conselho Nacional de Cultura foi fundado no mesmo ano através do Decreto no 5.520, de 24 de agosto de 2005. Estes Conselhos de Cultura (federal, estaduais ou municipais) constituem ambientes de pactuação de Políticas Públicas de Cultura, com o perfil deliberativo e consultivo, devendo ser compostos com $50 \%$ de representantes da sociedade civil, eleitos democraticamente, conforme a lei que rege o SNC. Os Conselhos integram a estrutura do órgão gestor de Cultura e devem agir formulando estratégias e controlando a execução das Políticas Públicas de Cultura.

No Amapá, o Conselho Estadual de Cultura (CONSEC-AP), é um órgão de deliberação coletiva, normativa, orientador e fiscalizador das atividades culturais do Estado do Amapá, criado pela Lei № 0911, de 01 de agosto de 2005 é paritário, sendo metade dos conselheiros indicados pelo Governo do Estado e a outra metade eleita pelos segmentos ali representados. 0 Conselho tem 16 membros titulares e 04 suplentes, cujas atividades enquanto conselheiros são gratificadas. O CONSEC funciona em prédio próprio numa área central da capital, Macapá, dispõe de 02 servidores, uma pequena galeria de Artes e não tem orçamento próprio.

Tal qual os Conselhos, as Conferências de Cultura representam um espaço de pactuação e articulação entre poder público e sociedade civil. As conferências são oportunidades para que juntos, estes entes proponham e avaliem as Políticas Públicas para o setor nas esferas da União, estados e municípios com vistas a formulação de propostas e aperfeiçoamento das ações. No Amapá, já foram realizadas três Conferências Estaduais de Cultura nos anos 2005, 2009 e 2013, com aumento significativo de participação, especialmente dos municípios mais distantes da capital.

Outro componente obrigatório do Sistema de Cultura são os Planos de Cultura. Plurianuais, estes planos constituem um conjunto de orientações com diretrizes e metas que devem subsidiar o desenvolvimento de programas, projetos e ações com 0 objetivo de assegurar a valorização, o reconhecimento, a promoção e a preservação da diversidade cultural. 0 Plano Nacional de Cultura foi instituído através da Lei $n^{\circ}$ 12.343, de 2 de dezembro de 2010, é composto por 53 metas, tem vigência por 10 anos, devendo ser reavaliado a cada 04 anos. No Amapá, Plano Estadual de Cultura está em fase de elaboração nas Câmara Setoriais que compõem o CONSEC-AP.

Um convênio entre o M inistério da Cultura e a Universidade Federal de Santa Catarina em parceria com o Fórum Nacional de Secretários Estaduais de Cultura, em 2012, possibilitou a capacitação de agentes governamentais de 17 estados para avaliar e contribuir na celeridade da implantação de seus sistemas estaduais por meio de oficinas, seminários, acompanhamento nos estados e capacitação à distância. Deste trabalho, resultou um Diagnóstico de Desenvolvimento da Cultura sobre a situação de adesão do Amapá à política nacional estabelecida. 0 Diagnóstico elenca alguns desafios a serem superados.

Estes desafios podem ser agrupados em três categorias: a) dos problemas decorrentes da ausência de mecanismos de financiamento e distribuição desigual de investimentos; b) da necessidade de produzir e acessar informações e pesquisas que fun- 
damentem a política cultural e profissionalizem mais trabalhadores do setor criativo; e c) da necessidade de um planejamento estadual que observe os processos produtivos e criativos locais a partir de sua diversidade e como um atrativo turístico da região. Isto tudo passa por uma formulação de Políticas Públicas marcadas pelo fortalecimento da diversidade cultural e pela incorporação da Cultura nos planos de Desenvolvimento estadual.

\subsection{A Cultura em três Planos Plurianuais do Amapá}

Os Planos Plurianuais, como instrumentos de planejamento criados na Constituição Federal de 1988, estabelecem diretrizes, objetivos e metas por um período de 04 anos, expressando quais as prioridades dos governos previstas para 0 atendimentos das Políticas Públicas. A constância ou ausência da Cultura nestes planos sugere de que maneira os governos recepcionaram todo o acúmulo de reflexões, normativas internacionais, mobilizações sociais e políticas nacionais acerca da percepção sobre a Cultura para as estratégias de Desenvolvimento. Além disso, conforme Burity (2007, p. 59-62), adquirirão melhores resultados, aquelas estratégias de Desenvolvimento que não prescindirem do diálogo com a cultura local, reconhecerem a Cultura para eficácia das Políticas Públicas e promoverem a participação das pessoas envolvidas como beneficiárias ou atingidas, reforçando, portanto, as identidades e diversidade locais.

Intitulado "Desenvolvimento com Justiça Social", o PPA 2004-2007 do Amapá, trata da área cultural a partir do planejamento dos macro-objetivos com vistas a fortalecer a infraestrutura do estado. A meta incide sobre o que é chamada de uma grande revitalização cultural, cujo intento é instituir um Centro de Referênci

a de Difusão de Cultura, além de incentivar o turismo cultural, sob a concepção de desenvolvimento humano a partir da formação de cidadãos, com respeito à diversidade étnica e cultural da região:

O desafio do crescimento e da justiça social passa pelo estabelecimento de infraestrutura física que dê suporte a uma rede de subsistemas adequados e a ações efetivas para iniciar uma grande jornada de revitalização social e econômica, em especial nas áreas de transporte, energia, telecomunicações, saneamento básico, educação e cultura. (PPA, 2003, p. 53)

Destaca-se que um dos desafios propostos para o Plano Plurianual 2004-2007, encontra-se voltado para a ideia de "resgatar, valorizar e difundir" as manifestações culturais, incentivando o desenvolvimento das populações indígenas, em defesa do princípio do pluralismo cultural. O PPA 2004-2007 assume enquanto responsabilidade do governo, o "resgate" de tradições e manifestações culturais, pautado em Programas e Ações em áreas de atuação específicas no intuito de proteger costumes, tradições e manifestações típicas de um povo. 
No período compreendido entre 2008-2011, entra em vigência o PPA intitulado Desenvolvimento com Inclusão Social e Educação de Qualidade", apresenta como resultado estratégico de governo, em seu eixo setorial econômico: "Geração de Emprego de Qualidade: promover a criação de mais empregos formais com salários mais elevados na economia amapaense, disseminando a cultura empreendedora no Estado na geração de trabalho e renda (PPA, 2007, p.30).

Em seu Eixo Setorial Social, o PPA 2008-2011 apresenta como proposta estratégica, o fortalecimento do atendimento da população nas áreas de Esporte e Lazer, e cita a ampliação do acesso da população à bens e serviços culturais oferecidos pelo governo, sem aprofundar, no entanto, o intento em metas, nem apresentar mais referências sobre Cultura.

O PPA 2012-2015, denominado "Tempo novo. Tempo de todos" também apresenta reunidos numa sessão, os setores de Educação, Cultura e Desportos, na qual objetiva-se para área valorizar a Cultura Amapaense, através de incentivo em seus vários segmentos, tendo como público-alvo a população em geral. Este PPA, prevê apoio a promoção de eventos culturais no Estado, além de dinamizar e valorizar os patrimônios e bens histórico-culturais do Amapá. A valorização da atividade artesanal no estado foi introduzida como incentivo ao desenvolvimento integral da atividade, elevando o nível cultural, social e profissional neste âmbito, destinada ao público artesão do estado e àqueles que possuem vocação para a atividade.

O investimento do PPA 2012-2015 para as Políticas Públicas para a Juventude observa a realização de eventos culturais e inserção do jovem no mercado de trabalho. No âmbito de programas de Pós-graduação, Pesquisa e Extensão, o PPA em questão, indica concentração de investimentos na área metropolitana do estado ${ }^{9}$ - compreendendo os municípios de Macapá e Santana - nos anos de 2013, 2014 e 2015, com a finalidade de possibilitar a formação profissional em áreas de Políticas Públicas, elevando o nível sociocultural da população Amapaense.

A análise destes instrumentos permite concluir que:

a) A política Nacional de Cultura pactuada entre os entes federados e a sociedade civil, amparada por instrumentos jurídicos federais e alicerçada por acordos internacionais, não se realiza nos PPAs.

b) A ausência de um Plano de Cultura que determine as prioridades do investimento público para área, resulta na imprecisão sobre programas, ações, projetos e orçamento, o que se expressa em objetivos muito amplos ou superficiais.

c) A considerar os convênios disponíveis no Portal da Transparência do Amapá, há também um claro descompasso entre o planejamento e execução dos objetivos pretendidos. Não houve por exemplo o fortalecimento da infraestrutura da Cultura, com a construção ou reforma de equipamentos culturais ou, mais precisamente, da construção de um Centro de Difusão Cultural. Tal qual, não foram disponibilizados programas culturais que atendessem em específico às demandas referentes às popu-

${ }^{9}$ Conforme Lei Complementar no 0021, de 26 de fevereiro de 2003. 
lações tradicionais como indígenas, quilombolas e ribeirinhas.

Desta dificuldade em objetivar as Políticas Culturais enquanto Políticas Públicas e estratégia de Desenvolvimento previstas nos PPA's, decorre a ausência de indicadores e informações que subsidiem o controle e o acompanhamento dos gastos públicos. Sem metas esclarecidas e com poucos dados e pesquisas, as Políticas Culturais no Amapá estendem um longo e enfático ciclo de apoio a eventos, concentração de recursos na capital e invisibilização da diversidade.

Assim, se antes as políticas de estado eram criadas para reforçar o conceito de estadonação com base na unidade e homogeneidade da população, atualmente se constituem por iniciativas e participação das comunidades na gestão, e contribuem para o sentido da multiplicidade e da pluralidade. 0 desafio está em estabelecer, continuamente, variadas possibilidades de conexões entre culturas diferentes, realidades sociais distintas e possibilitar sempre o encontro entre os homens contribuindo para a valorização da dignidade humana e para a promoção da cidadania como base do desenvolvimento da região, lócus singular para identificação, promoção e proteção da diversidade cultural, preconizada pelos instrumentos internacionais.

\section{CONSIDERAÇÕES FINAIS}

As relações históricas e epistemológicas da relação entre cultura e desenvolvimento são complexas e entremeadas de múltiplas abordagens teóricas, com definições conceituais distintas em cada âmbito disciplinar e enviesadas por aspectos ideológicos. Sem a pretensão de esgotar as reflexões sobre o tema, este artigo se prestou a investigar como se deu a incorporação da cultura ao desenvolvimento considerando as narrativas internacionais que regeram essas relações do século XIX à contemporaneidade.

A partir disso, foi possível compreender que uma mudança significativa na valoração do papel da cultura foi se ampliando à medida que o crescimento econômico, enquanto condição exclusiva do desenvolvimento, passou a ser questionado. 0 fracasso de modelos replicados de outras regiões, o impacto da globalização sobre as identidades passou a ser foco da atenção de organismos internacionais. Este processo se deu concomitantemente às funções assumidas pela cultura em âmbito global.

Seja através da reorganização da sociedade, do meio ambiente, dos recursos econômicos ou materiais, como decorrência da globalização e avanço tecnológico, a cultura engendrou das relações internacionais, à vida social, o trabalho e identidade/subjetividade dos indivíduos, dando sustentação ao que se define como "Revoluções Culturais". É neste contexto que também ocorre a "Virada Cultural": uma serie de contribuições epistemológicas que passaram a se destacar nas ciências, forçando que se repensasse sobre a centralidade da cultura na análise social.

Os direitos culturais e os debates internacionais interagem de maneira que as Políticas Culturais tenham cada vez mais um caráter transnacional, principalmente a par- 
tir de sua vinculação com a ideia de desenvolvimento. Tem-se como maior influência no ordenamento jurídico que norteia as Políticas Públicas de várias nações e o próprio direito internacional, a Declaração Universal dos Direitos Humanos, expressando a necessidade de proteção de vários direitos fundamentais, assegurando a todas as pessoas, o direito de participação da vida cultural da comunidade, a fruição pelas artes e o compartilhamento dos benefícios decorrentes progresso científico.

0 contexto e as contribuições mencionadas parecem ter incidido nos paradigmas de desenvolvimento contemporâneos. Como expressão disso, os tratados internacionais se lançam a multidimensionalidade do desenvolvimento asseverando o mínimo de proteção à dignidade humana e foco na vida das pessoas. De tal forma que, a cultura como condição sine qua non de formação da pessoa e, portanto, de vida humana demonstra-se como essencial para efetivação do direito ao desenvolvimento.

Quando se trata da região, é preciso ter claro que a despeito da visão romântica que domina o senso comum sobre a homogeneidade do território amazônico, a diversidade cultural e a produção artística dessa região revela a incrível multiplicidade que a compõem. Entretanto, as limitações históricas procedentes da ocupação do norte brasileiro ainda interferem decisivamente no processo de fruição, no acesso aos bens culturais aqui produzidos e na valorização do patrimônio cultural. 0 Amapá é dos estados da região Amazônica com maiores problemas para o escoamento de seus produtos culturais, análise que se estende também divulgação e a circulação deles, tendo em vista a ausência de banda larga e a inexistência de comunicação rodoviária com outro estado brasileiro.

Não é novidade que a Cultura seja preterida nestes planejamentos ou que conste exclusiva numa alínea de função orçamentária. No caso do Amapá, analisando os Planos Plurianuais-PPAs de 2004-2007, 2008-2011 e 2012-2015, pode-se observar a brevidade com que é tratado o tema, dificultando objetivar as diretrizes gerais do plano proposto, bem como o estabelecimento de metas mensuráveis, geradoras de indicadores favoráveis de Desenvolvimento e em consonância com a Política de Cultura Nacional pactuada junto a sociedade civil.

\section{REFERÊNCIAS}

AM APÁ. Decreto no 4823, de 28 de outubro de 2005. Regulamenta a Lei Estadual no 0777, de 14 de outubro de 2003, alterada pela Lei Estadual no 0912, de 01 de agosto de 2005, que dispõe sobre o incentivo fiscal para a realização de projetos culturais, no Estado do Amapá e dá outras providências. Disponível em http:// www.marketingcultu ral.com.br/leis/decreto-4823-am.htm. Acessado em: 13 nov. 2015.

. Decreto-lei n. 1073, de 02 de abril de 2007. Altera dispositivos da Lei o․ 0811, de 20 de fevereiro de 2004, que dispõe sobre a Organização do Poder Executivo do Estado do Amapá e dá outras providências. Disponível em http://www.al.ap.gov.br/ ver_texto_consolidado.php?iddocumento=22319. Acessado em: 13 nov. 2015. 
. Lei 0912, de 1 de agosto de 2005. Altera dispositivos da Lei no 0777, de 14 de outubro de 2003, que dispõe sobre o incentivo fiscal para a realização de projetos culturais no âmbito do Estado do Amapá. Disponível em https://www.sefaz.ap.gov.br/index. php/2005/7805-lei-n-0912-de-01-de-agosto-de-2005-altera-dispositivos-da-lei-n-0777de-14-de-outubro-de-2003-que-dispoe-sobre-o-incentivo-fiscal-para-a-realizacao-deprojetos-culturais-no-ambito-do-estado-do-amapa. Acessado em: 13 nov. 2015.

. Lei n. 0021, de 26 de fevereiro de 2003. Institui a Região Metropolitana do Município de Macapá, Estado do Amapá, e dá outras providências. Disponível em https:// www.sefaz.ap.gov.br/index. php/2003/8131-lei-complementar-n-0021-de-26de-fevereiro-de-2003. Acessado em: 13 nov. 2015.

. Lei n. 0101, de 02 de setembro de 1993. Autoriza o Poder Executivo a instituir a Fundação Estadual de Cultura e dá outras providências. Disponível em: «ttp://ww w.al.ap.gov.br/ver_texto_lei.php?iddocumento=24>Acessado em: 13 nov. 2015.

. Lei n. 0911, de 1 de agosto de 2005. Dispõe sobre a criação do Conselho Estadual de Cultura e dá outras providências. Disponível em http:// www.al.ap.gov.br/ver texto_consolidado.php?iddocumento=20954. Acessado em: 13 nov. 2015.

. Lei n. 1520, de novembro de 2010. Dispõe sobre a criação do "Fundo Estadual de Arte e Cultura do Amapá" e dá outras providências. Disponível em http://www.al.ap. gov.br/ver_texto_lei.php?iddocumento $=20238$. Acessado em: 13 nov. 2015.

BARBALHO, Alexandre. Política Cultural. Salvador: P55 Edições, 2013. (Col. Política e Gestão Culturais).

BRANT, Leonardo. 0 poder da Cultura. Rio de Janeiro: Petrópolis, 2009. BRASIL. Decreto n. 5520, de 24 de agosto de 2005. Institui o Sistema Federal de Cultura - SFC e dispõe sobre a composição e o funcionamento do Conselho Nacional de Política Cultural - CNPC do Ministério da Cultura, e dá outras providências. Disponível em http://www.planalto.gov.br/ccivil_03/_ato2004-2006/2005/Decreto/D5520.htm. Acessado em: 13 nov. 2015.

BRASIL. Lei n. 4.320 de 17 de março de 1964. Estatui Normas Gerais de Direito Financeiro para elaboração e contrôle dos orçamentos e balanços da União, dos Estados, dos Municípios e do Distrito Federal. Disponível em http://www.planalto.gov.br/cci vil_03/leis/L4320.htm Acessado em: 13 nov. 2015.

BRASIL. Lei n. 5812, de 13 de setembro de 1943. Cria os Territórios Federais do Amapá, do Rio Branco, do Guaporé, de Ponta Porã e do Iguassú. Disponível em http://www.planalto.gov.br/ccivil_03/decreto-lei/1937-1946/_Del5812.htm.

BRASIL. Lei n. 8313, de 23 dezembro de 1991. Restabelece princípios da Lei ${ }^{\circ} 7.505$, de 2 de julho de 1986, institui o Programa Nacional de Apoio à Cultura (Pronac) e dá outras providências. Disponível em http://www.planalto.gov.br/ccivil_03/leis/L8313 cons.htm.

BRASIL. Lei no 12.343, de 2 de dezembro de 2010. Institui o Plano Nacional de Cultura - PNC, cria o Sistema Nacional de Informações e Indicadores Culturais - SNIIC e dá outras providências. Disponível em http://www2.camara.leg.br/legin/fed/lei/2010/lei- 
12343-2-dezembro-2010-609611-norma-pl.html. Acessado em: 13 nov. 2015.

BURITY, Joanildo. Cultura \& desenvolvimento. In: RUBIM, Antonio Albino Canelas. Políticas culturais: entre o possível e o impossível. Teorias e políticas da cultura: visões multidisciplinares. Salvador: Edufba, 2007. (p. 51-66).

IBGE - Instituto Brasileiro de Geografia e Estatística. Censo Demográfico. Rio de Janeiro: IBGE, 2010. Disponível em http://censo2010.ibge.gov.br/ . Acessado em: 02 dez. 2015.

CHELALA, Charles Achcar. A magnitude do Estado na socioeconomia amapaense. Macapá: Unifap, 2008.

COELHO, Texeira. Apresentação. In: M EYER-BISCH, Patrice; BIDAULT, M ylène (orgs.). Afirmar os Direitos Culturais: comentário à Declaraçaão de Friburgo. Tradução: Ana Goldberger. São Paulo: Editora lluminuras, 2014.

COM PARATO, Fábio Konder. A afirmação histórica dos direitos humanos. São Paulo: Saraiva, 2013.

CONTAS REHIONAIS 2013. RIO de Janeiro: IBGE, 2015 Disponível em http://ibge.gov. $\mathrm{br} /$ home/estatistica/ economia/contasregionais/2013/default.shtm. Acessado em: 20/08/2016

ESCOSTEGUY, Ana Carolina D. Cartografias dos estudos culturais: uma versão. Belo Horizonte: Autêntica, 2001.

HALL, Stuart. A centralidade da cultura: notas sobre as revoluções culturais do nosso tempo. Educação \& Realidade. 22.2, 1997.

M ATA-M ACHADO, Bernardo Novais. Direitos humanos e direitos culturais. 2007. Disponível em http://www.direitoecultura.com.br/wp-content/uploads/Direitos-Huma nos-e-Direitos-Culturais-Bernardo-Novais-da-M ata-M achado.pdf. Acessado em: 20 de jul. de 2015.

M EYER-BISCH, Patrice; BIDAULT, M ylène (orgs.). Afirmar os Direitos Culturais: comentário à Declaração de Friburgo. Tradução: Ana Goldberger. São Paulo: Editora Iluminuras, 2014.

ONU. Declaração sobre o Direito ao Desenvolvimento, 1986. Disponível em http://w www.direitoshumanos.usp.br/index. php/Direito-ao-Desenvolvimento/declaracao-sobre-o-direito-ao-desenvolvimento.html. Acessado em: 13 nov. 2015.

ONU. Declaração Universal dos Direitos Humanos, 1948. Disponível em http://www. dudh.org.br/wp-content/uploads/2014/12/dudh.pdf. Acessado em: 02 nov. 2015.

PIOVESAN, Flávia. Direito ao Desenvolvimento. In: Anais do Colóquio Internacional de Direitos Humanos, 2. São Paulo: Fundação das Nações Unidas/ Fundação Ford, 2002. Pdf

QUINTAS, Heluana. Políticas Culturais e Desenvolvimento: uma proposta de Índice Cultural para a cidade de Macapá - AP. 2016. 195 f. Dissertação (Mestrado em Desenvolvimento Regional) - PPGM DR. Universidade Federal do Amapá - M acapá. RUBIM, Antonio Albino Canelas. Políticas culturais: entre o possível e o impossível. In: Teorias e políticas da cultura: visões multidisciplinares. Salvador: Edufba, 2007, p. 
139-157.

SANTOS, Boaventura de Sousa. Por uma concepção multicultural de direitos humanos. Lua nova, v. 39, p. 105-124, 1997.

SEN, Amartya. Desenvolvimento como liberdade. Tradução: Laura Texeira Motta. São Paulo: Companhia das Letras, 2000.

SEN, Amartya. KLIKSBERG, Bernardo. As pessoas em primeiro lugar: a ética do desenvolvimento e os problemas do mundo globalizado. Tradução: Bernardo Ajzemberg, Carlos Eduardo Lins da Silva. São Paulo: Companhia das letras, 2010.

SEN, Amartya. La cultura como base do desarollo. In: Revista Diálogo. Caracas: UNESCO, 1998. http:// www.unrc.edu.ar/publicar/25/dos.html. Acessado em: 15 set. 2014. SOARES JÚNIOR, Jair. ; QUINTELLA, Rogério H. Instrumentalização do desenvolvimento: teorias, conceitos e indicadores. Revista Organizações \& Sociedade. v. 15, n. 45, 2014.

SOUZA, Allan R Os direitos culturais no Brasil. Rio de Janeiro: Azougue Editorial, 2012. SUPERTI, Eliane; SILVA, Gutemberg de Vilhena. Comunidades Quilombolas na Amazônia:. construção histórico-geográfica, características socioeconômicas e patrimônio cultural no Estado do Amapá. Confins. Revue franco-brésilienne de géographie/Revista Franco-Brasilera de Geografia, n. 23, 2015.

VARELLA, Guilherme. Plano Nacional de Cultura: Direitos e políticas culturais no Amapá. Rio de Janeiro: Azougue, 2014.

Artigo recebido em 01 de novembro de 2016.

Aprovado em 16 de novembro de 2016. 